\title{
Carcinogenic Health Risk of Arsenic in Five Commercially Important Fish from Laguna De Bay, Philippines
}

\author{
Victorio B. Molina ${ }^{1}$ and Ryohei Kada ${ }^{2,3}$ \\ ${ }^{1}$ Department of Environmental and Occupational Health, College of Public Health, University of the Philippines Manila \\ ${ }^{2}$ Shijyonawate Gakuen University, Osaka, Japan \\ ${ }^{3}$ Research Institute for Humanity and Nature, Kyoto, Japan \\ 457-4 Motoyama Kamigamo, Kita-ku, Kyoto 603-8047 Japan
}

\begin{abstract}
Objective. This paper examines the potential carcinogenic risk to human health associated with arsenic levels in five commercially important fish products from Laguna de Bay.

Methods. Fish samples were collected in eight sampling stations in three major areas of the lake during the dry and wet seasons. Coordinates of sampling locations were recorded using Global Positioning System and plotted in Geographic Information System digital maps. Analysis of arsenic was conducted using Atomic Absorption Spectrophotometer.
\end{abstract}

Results. The highest life time cancer risk for arsenic was computed for tilapia from sampling station $2 \mathrm{~B}$ during the dry season with risk value of $8.51 \times 10^{-5}$ or about 85 excess cancer cases per $1,000,000$ populations. Calculated cancer risks showed seasonal variations that were distinct among the five fish species. Excess life time cancer risks associated with fish consumption during dry season showed the following order of magnitude: Tilapia $>$ Bighead carp $>$ Kanduli $>$ Bangus $>$ Dalag. For wet season, the order of magnitude was: Bighead carp $>$ Bangus $>$ Kanduli $>$ Tilapia $>$ Dalag. Correlation analyses showed that fish mean standard size do not have significant effect on the levels of arsenic in fish samples for both dry and wet seasons.

Conclusion. This study concludes from the point of view of disease prevention that long-term consumption of five commercially important fish species from Laguna de Bay may cause significant carcinogenic health risk.

Key Words: bioaccumulation, cancer, fish, arsenic, carcinogenic risk, Laguna de Bay.

\section{Introduction}

Heavy metals from natural sources and anthropogenic activities are continually released into aquatic environment, causing serious threat due to their toxicity, long persistence and biomagnification in the food chain. On a global scale,

\footnotetext{
Corresponding author: Victorio B. Molina, MPH, PhD

Department of Environmental and Occupational Health,

College of Public Health, University of the Philippines Manila

625 Pedro Gil Street, Ermita Manila, Philippines 1000

Telephone: +632 5247102

Fax No.: +6325237745

Email: vbmolina@post.upm.edu.ph
}

pollution of heavy metals in aquatic ecosystem is growing at an alarming rate and has become an important environmental health problem. ${ }^{1,2}$ Rapid development of industry and agriculture has contributed to increasing pollution of rivers and lakes with heavy metals, which have been identified as significant environmental hazard for invertebrates, fish and humans. ${ }^{3}$ These contaminants entering the aquatic ecosystem may not directly damage the organisms but they can be deposited into aquatic organisms through the effects of bioaccumulation and food chain process and eventually threaten the health of humans through fish consumption. ${ }^{4}$ Fish being situated at high trophic level of food web may accumulate large amounts of heavy metal from water and often in concentrations several times higher than in the ambient water. $^{1}$ Some of metals found in fish might be essential as they play important role in biological system of fish as well as in human beings. However, some of it may also be toxic and might cause serious damage in human health even in trace amount at a certain limit or threshold. Deleterious human health effects associated with exposure to heavy metals, even at low concentrations, are diverse and include but are not limited to, neurotoxic and carcinogenic consequences. ${ }^{5}$

Arsenic is a heavy metal that is widely distributed in the environment due to natural and anthropogenic activities and often found in water, food, soil and airborne particles. In recent years, contamination of the aquatic environment by arsenic has increased primarily due to anthropogenic sources. ${ }^{6,7}$ Arsenic toxicity depends on its concentration, speciation, bioavailability and uptake. Inorganic arsenic is more toxic than organic compounds and is proven carcinogen to humans. ${ }^{8,9}$ Trivalent compounds are generally more toxic than pentavalent compounds, and water soluble compounds are usually more toxic and more likely to have systemic effects than the less soluble compounds. ${ }^{10}$

Human exposure to arsenic can be increased by cigarette smoking, but food remains as prime source of ingestion. In the environment and food, arsenic could be in the organic and inorganic forms. ${ }^{11}$ In humans, arsenate $(\mathrm{AsV})$ is first reduced to arsenite (AsIII), itself methylated into methylarsonic and dimethylarsenic acids (MMA and DMA), most of which are then excreted via the renal 
pathway. ${ }^{12}$ Previous studies have found that exposure to arsenic may lead to cancers of liver, kidney, bladder, prostate, lymphoid tissue, skin, colon, lung and nasal cavity, among others. The International Agency for Research on Cancer (IARC) has classified arsenic as group 1 carcinogen, indicating that sufficient evidence of human carcinogenicity exist. $^{13}$

Fish has been known for its reputation as the established health food for most of the worlds' population particularly in developing countries as compared to meat, poultry and eggs. ${ }^{14}$ Nutritional benefits of fish are mainly due to the content of high quality protein, vitamins and essential nutrients. Fatty fish are high in two kinds of omega-3 polyunsaturated fatty acids (PUFAs): eicosapentaenoic acid (EPA) and docosahexaenoic acid (DHA). ${ }^{15}$ Modest consumption of fish especially species with high in n-3 fatty acids EPA and DHA, reduces risks of coronary deaths by $36 \%$ and total mortality by $17 \%$ and may favorably affect other clinical outcomes. ${ }^{16}$ Incidentally, many fish are also contaminated with harmful substances like heavy metals and other chemical compounds that bioaccumulate overtime. ${ }^{17}$

Health risk assessment is frequently employed to quantify potential threats to human health through an exposure-bioaccumulation-ingestion pathway of toxic substances in aquatic organisms. ${ }^{18}$ It is the process to estimate nature and probability of adverse health effects in humans who may be exposed to chemicals in contaminated environmental media. ${ }^{19}$ Assessment of human health risk requires identification, compilation and integration of information on health hazards of a chemical, human exposure to chemical and relationships among exposure, dose and adverse effects. ${ }^{20}$ Results of assessment are used to estimate whether current or future chemical exposures will pose health risks to broad population. However, methods used in health risk assessment cannot be used to link individual illnesses to past chemical exposures nor prove that a specific toxic substance caused particular illness in individuals. ${ }^{21}$ In this paper, health risk assessment of arsenic in fish intends to contribute to scientific knowledge of understanding risks versus benefits of fish consumption in Laguna de Bay.

The Philippine Millennium Ecosystem Assessment Subglobal Assessment for Laguna Lake emphasized that Laguna de Bay is a classic model of multiple resource with multiple users. Its capacity to provide various ecosystem services to various users is continuously challenged mainly by anthropogenic factors. Deforestation of its watersheds in favor of other uses is expected to cause an imbalance in the lake hydraulic processes. Lake water quality has deteriorated through the years due to various point sources of pollution from industry, agriculture, and domestic sources. Detection of traces of heavy metals like copper, cadmium, chromium, and lead in lake water and sediment is a major concern for human health. ${ }^{22}$ The main objective of this study is to assess the carcinogenic risks to human health due to arsenic in commercially important edible fish products from Laguna de Bay. This study also aims to provide logical basis for appropriate risk communication interventions regarding health implications of long term fish consumption to stakeholders.

\section{Methods}

Laguna de Bay basin is situated within latitudes of $13^{\circ}$ $55^{\prime}$ to $14^{\circ} 50^{\prime} \mathrm{N}$ and longitudes of $120^{\circ} 50^{\prime}$ to $121^{\circ} 45^{\prime} \mathrm{E}$ in Luzon Islands, Philippines, with total area of about 3,813.2 $\mathrm{km}^{2}$. It traverses 12 cities, 49 municipalities, and 2,656 barangays or villages. The Laguna de Bay, also known as Laguna Lake, is one of the five largest freshwater lakes in Southeast Asia. Total surface area is approximately $900 \mathrm{~km}^{2}$ with shoreline of $220 \mathrm{~km}$. It has an average depth of $2.5 \mathrm{~m}$ and maximum water holding capacity of about 2.9 billion cubic meters. Geographically, the lake can be divided into west bay, east bay, south bay, and central bay. ${ }^{22}$

\section{Sampling zones and sites}

Laguna de Bay was divided into five sampling zones: namely, Northern West Bay, Central West Bay, Central Bay, South Bay, and East Bay. Fish samples were collected from each of the five designated sampling zones. There were two sampling sites each for Northern West Bay, Central West Bay, and Central Bay; and one sampling site each for South Bay, and East Bay; for a total of eight sampling sites. Sampling location coordinates were recorded using GPS and plotted in GIS digital maps. Locations and coordinates of sampling sites are shown in Table 1. This facilitated resampling activities and ensured that subsequent samples for wet season were collected in the area as that of the dry season samples. A GIS map of Laguna de Bay is shown in Figure 1.

Table 1. Sampling site locations and coordinates.

\begin{tabular}{|c|c|c|}
\hline FISH SAMPLING SITE & LOCATION & COORDINATES \\
\hline $1 \mathrm{~A}$ & Northern West Bay & $\begin{array}{l}\text { N } 14^{\circ} 28^{\prime} 57.8^{\prime \prime} \\
\text { E } 121^{\circ} 09^{\prime} 22.6^{\prime \prime}\end{array}$ \\
\hline 1B & Northern West Bay & $\begin{array}{l}\mathrm{N} 14^{\circ} 27^{\prime} 50.6^{\prime \prime} \\
\text { E } 121^{\circ} 05^{\prime} 19.3^{\prime \prime}\end{array}$ \\
\hline $2 \mathrm{~A}$ & Central West Bay & $\begin{array}{l}\text { N } 14^{\circ} 22^{\prime} 34.1^{\prime \prime} \\
\text { E } 121^{\circ} 12^{\prime} 03.6^{\prime \prime}\end{array}$ \\
\hline 2B & Central West Bay & $\begin{array}{l}\mathrm{N} 14^{\circ} 22^{\prime} 43.4^{\prime \prime} \\
\mathrm{E} 121^{\circ} 04^{\prime} 30.1^{\prime \prime}\end{array}$ \\
\hline $3 \mathrm{~A}$ & Central Bay & $\begin{array}{l}\text { N } 14^{\circ} 22^{\prime} 43.9^{\prime \prime} \\
\text { E } 121^{\circ} 19^{\prime} 25.5^{\prime \prime}\end{array}$ \\
\hline 3B & Central Bay & $\begin{array}{l}\mathrm{N} 14^{\circ} 28^{\prime} 13.5^{\prime \prime} \\
\mathrm{E} 121^{\circ} 13^{\prime} 19.4^{\prime \prime}\end{array}$ \\
\hline 4 & South Bay & $\begin{array}{l}\mathrm{N} 14^{\circ} 11^{\prime} 41.4^{\prime \prime} \\
\mathrm{E} 121^{\circ} 11^{\prime} 43.5^{\prime \prime}\end{array}$ \\
\hline 5 & East Bay & $\begin{array}{l}\mathrm{N} 14^{\circ} 22^{\prime} 12.9^{\prime \prime} \\
\mathrm{E} 121^{\circ} 25^{\prime} 28.8^{\prime \prime}\end{array}$ \\
\hline
\end{tabular}




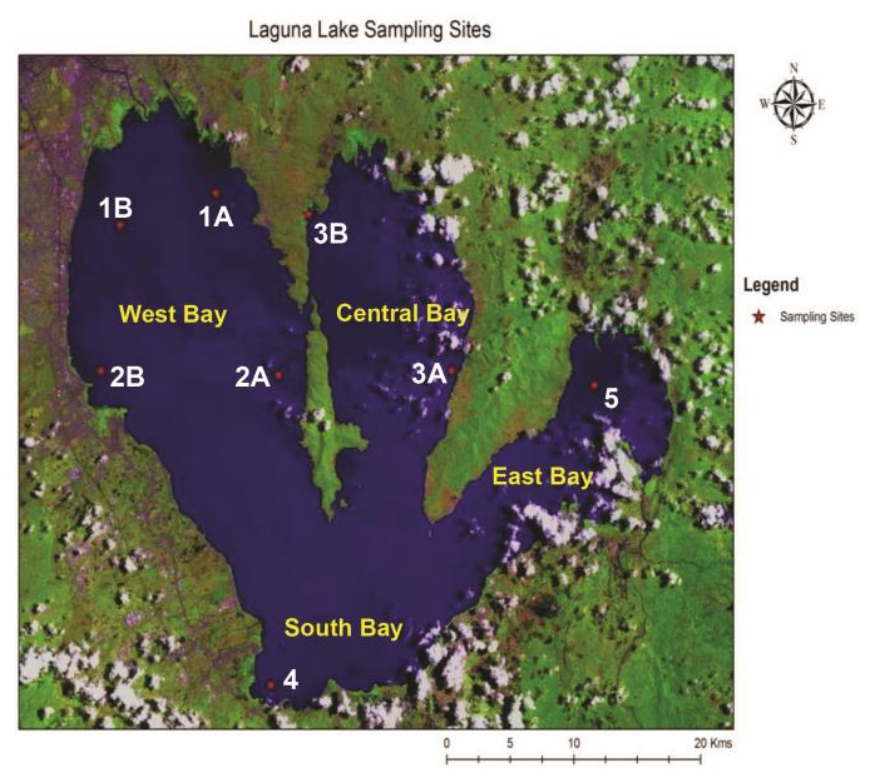

Figure 1. Location of sampling sites (GIS map).

\section{Sampling frequency}

Two groups of fish samples were collected using fish net to determine seasonal variation in arsenic levels in fish. First set of samples was collected in May to June 2010 to represent dry season conditions in the study area. Second set was collected during the months of September to November 2010 to represent wet season.

\section{Fish species}

Selection of fish species included in the study was based on most common edible species harvested in the lake with relatively high commercial value. There were five fish species included in the study, namely, Bighead Carp, Kanduli, Bangus, Tilapia, and Dalag. Bangus and bighead carp are considered as pelagic species. Dalag and kanduli are demersal species; while, tilapia is considered as both pelagic and demersal species. Description of fish species is shown in Table 2.

Table 2. List of common and scientific names of fish species included in the study.

\begin{tabular}{lll}
\hline COMMON NAME & \multicolumn{1}{c}{ ENGLISH NAME } & SCIENTIFIC NAME \\
\hline Mamaling & Bighead carp & Aristichthys nobilis \\
Kanduli & Manila Catfish & Arius dispar \\
Tilapia & Tilapia & Oreochromis niloticus \\
Dalag & Snakehead/Murrel/Mudfish & Ophicephalus striatus \\
Bangus & Milk Fish & Chanos chanos \\
\hline
\end{tabular}

\section{Sample packaging and preservation}

Fish samples were individually wrapped in waterproof plastic sampling bag. Edible portions of samples were processed on-site to avoid puncturing of the packaging material by spines during transport. Individual samples were sealed in three layers of plastic bags. Each sample was provided with identification tag and sample code. After packaging, samples were kept in an ice chest and brought to the laboratory immediately.

\section{Laboratory procedures and analysis}

Samples submitted to the Philippine Department of Science and Technology laboratory for analysis were stored in freezer until all samples had been collected to ensure uniform sample preparation. Prior to analyses, samples were thawed then osterized for homogeneity. Replicates were prepared and all quality control parameters were conducted to ensure integrity of analyses. Samples were analyzed using the Atomic Absorption Spectrophotometer. The sample solutions were aspirated into a flame and atomized. Arsenic analysis involves the generation of arsine gas by reacting the arsenic in the sample with sodium borohydride.

\section{Basic equation for calculating excess lifetime cancer risk}

Arsenic is confirmed human carcinogen through the oral route of exposure. Chronic oral exposure to arsenic has been linked to various types of internal cancers, including those of the liver, bladder, and respiratory and gastrointestinal tracts. Slope factors and unit risk values are used to assess cancer risk. Generally, the slope factor is a plausible upper-bound estimate of the probability of a response per unit intake of a chemical over a lifetime. Slope factor is used in risk assessments to estimate an upperbound lifetime probability of an individual developing cancer as a result of exposure to a particular level of a potential carcinogen. Oral slope factor evaluates the probability of an individual developing cancer from oral exposure to contaminant levels over a lifetime. Oral slope factors are expressed in units of $\left(1 / \mathrm{mg} / \mathrm{kg}\right.$-day).${ }^{10}$

The basic equation for calculating excess lifetime cancer risk is:

Where:

$$
\text { Risk }=\mathrm{CDI} \times \mathrm{SF}
$$

Risk = a unit less probability of an individual developing cancer over a lifetime;

$\mathrm{CDI}=$ chronic daily intake or dose $[\mathrm{mg} / \mathrm{kg}$-day $]$

$\mathrm{SF}=$ slope factor, expressed in $\left[(\mathrm{mg} / \mathrm{kg} \text {-day })^{-1}\right]=1.5[(\mathrm{mg} / \mathrm{kg}-$ day) ${ }^{-1}$ for inorganic Arsenic

Carcinogenic Fish Ingestion Equation: $\mathrm{CDI}_{(\mathrm{c})}$

$$
\mathrm{CDI}(\mathrm{c})=\frac{\mathrm{C} \times \mathrm{EF} \times \mathrm{ED} \times \mathrm{IRF} \times(\mathrm{kg} / 1000 \mathrm{~g})(0.10)}{(365 \text { days/year }) \times \mathrm{LT} \times \mathrm{BW}}
$$

Where:

$\mathrm{CDI}=$ chronic daily intake for the toxicant expressed in $\mathrm{mg} / \mathrm{kg}$-day

$\mathrm{C}=$ Concentration of heavy metal in fish $(\mathrm{mg} / \mathrm{kg})$

BW $=$ Body Weight $=65 \mathrm{~kg}$ 
$0.10=$ Factor to convert total arsenic to inorganic arsenic fraction

$\mathrm{ED}=$ Exposure Duration $=30 \mathrm{yrs}$

$\mathrm{EF}=$ Exposure frequency $=350$ days $/ \mathrm{yr}$

IRF=Ingestion Rate Fish (fish consumption) = $102.74 \mathrm{~g} /$ day (FAO). This is the estimated average daily per capita consumption of fish in the Philippines from the FAO Fisheries and Aquatic Department.

$\mathrm{LT}=$ Lifetime (average) $=70$ years for carcinogenic

Equation for lifetime cancer risk:

$$
\text { Risk }=\frac{\mathrm{C} \times \mathrm{EF} \times \mathrm{ED} \times \mathrm{IRF} \times(\mathrm{kg} / 1000 \mathrm{~g})(0.10)}{(365 \text { days/year }) \times \mathrm{LT} \times \mathrm{BW}} \times(\mathrm{SF})
$$

\section{Equation for linear correlation coefficient (r)}

The Linear correlation coefficient measures the strength and the direction of a linear relationship between two variables (Pearson product moment correlation coefficient).

The mathematical formula for computing " $r$ " is:

$$
r=\frac{n \sum x y-\left(\sum x\right)\left(\sum y\right)}{\sqrt{n\left(\sum x^{2}\right)-\left(\sum x\right)^{2} \sqrt{n\left(\sum y^{2}\right)-\left(\sum y\right)^{2}}}}
$$

Where $n$ is the number of pairs of data. Value of $r$ can range from -1 to +1 (i.e., $-1 \leq r \leq+1$ ) where the + and - signs indicate positive linear correlations and negative linear correlations, respectively.

\section{Results}

\section{Arsenic levels in fish for dry season}

Figure 2 shows the concentrations of arsenic in fish samples in $\mathrm{mg} / \mathrm{kg}$ wet weight from eight sampling stations for dry season. Concentration of arsenic in bangus ranged from $0.03473 \mathrm{mg} / \mathrm{kg}$ in sampling station $3 \mathrm{~B}$ to $0.16798 \mathrm{mg} / \mathrm{kg}$ in station 4. In Bighead Carp it ranged from $0.02858 \mathrm{mg} / \mathrm{kg}$ in station $1 \mathrm{~B}$ to $0.19239 \mathrm{mg} / \mathrm{kg}$ in station 4. Dalag concentration ranged from $0.001 \mathrm{mg} / \mathrm{kg}$ in stations $2 \mathrm{~A}, 3 \mathrm{~A}$ and $3 \mathrm{~B}$ to $0.04696 \mathrm{mg} / \mathrm{kg}$ in station $1 \mathrm{~B}$. Kanduli concentration ranged from $0.001 \mathrm{mg} / \mathrm{kg}$ in stations $2 \mathrm{~A}, 2 \mathrm{~B}, 3 \mathrm{~A}$ and $3 \mathrm{~B}$ to $0.09517 \mathrm{mg} / \mathrm{kg}$ in station 4. While in Tilapia the concentration ranged from $0.001 \mathrm{mg} / \mathrm{kg}$ in stations $1 \mathrm{~A}, 2 \mathrm{~A}$ and 5 to $0.160666 \mathrm{mg} / \mathrm{kg}$ in station 1B.

\section{Arsenic levels in fish for wet season}

Figure 3 shows the concentrations of arsenic in fish in $\mathrm{mg} / \mathrm{kg}$ wet weight from eight sampling stations for wet season. Concentration of arsenic in bangus ranged from $0.05769 \mathrm{mg} / \mathrm{kg}$ in sampling station $3 \mathrm{~B}$ to $0.65661 \mathrm{mg} / \mathrm{kg}$ in station 1A. In Bighead Carp it ranged from $0.09545 \mathrm{mg} / \mathrm{kg}$ in station $3 \mathrm{~A}$ to $0.99717 \mathrm{mg} / \mathrm{kg}$ in station 2B. Dalag concentration ranged from $0.00003 \mathrm{mg} / \mathrm{kg}$ in station $3 \mathrm{~B}$ to $0.36976 \mathrm{mg} / \mathrm{kg}$ in station $1 \mathrm{~A}$. Kanduli concentration ranged from $0.00003 \mathrm{mg} / \mathrm{kg}$ in station 3B to $0.73765 \mathrm{mg} / \mathrm{kg}$ in station 3A. While in Tilapia the concentration ranged from 0.02989 $\mathrm{mg} / \mathrm{kg}$ in station 4 to $0.87292 \mathrm{mg} / \mathrm{kg}$ in station $2 \mathrm{~B}$.

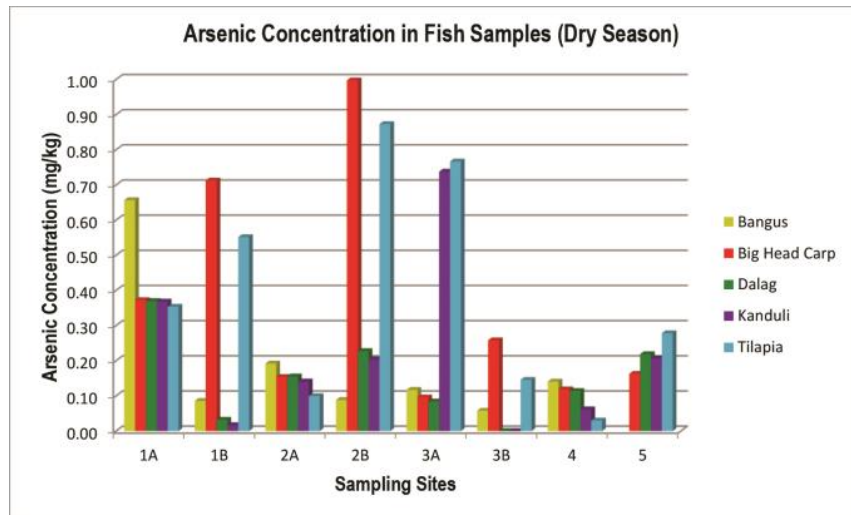

(West Bay $=1 \mathrm{~A}, 1 \mathrm{~B}, 2 \mathrm{~A}$ and 2B $/$ Central Bay $=3 \mathrm{~A}$ and 3B $/$ South Bay $=4$ / East Bay $=5$ )

Figure 2. Arsenic concentration (wet weight), fish (mg/kg), dry season.

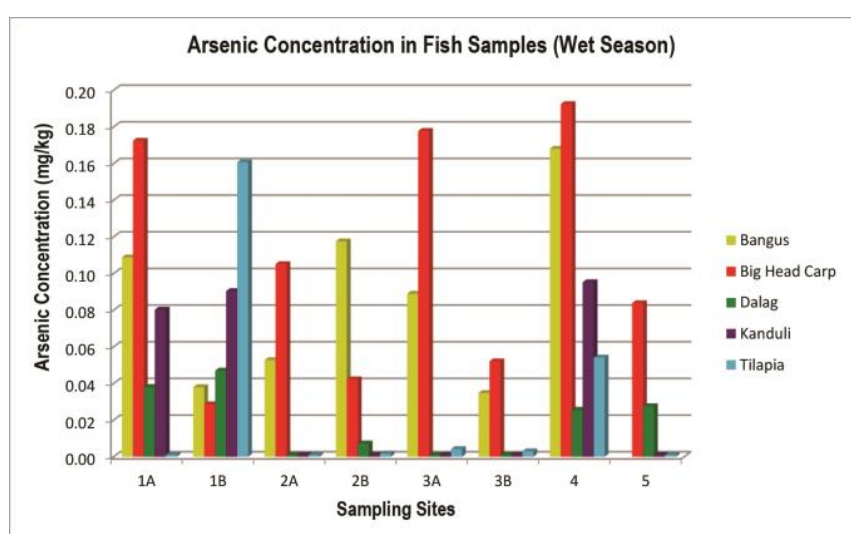

(West Bay $=1 \mathrm{~A}, 1 \mathrm{~B}, 2 \mathrm{~A}$ and 2B $/$ Central Bay $=3 \mathrm{~A}$ and 3B $/$ South Bay $=4 /$ East Bay $=5$ )

Figure 3. Arsenic concentration (wet weight), fish (mg/kg), wet season.

Laboratory data showed that generally the concentrations of arsenic in fish samples were higher during the dry than wet season. These values were used as basis for estimating the carcinogenic health risks of arsenic through ingestion. It appears that rainwater had positive outcome on the levels of arsenic in fish probably due to the dilution effect of rainwater run-off in most sampling sites except station 4 .

\section{Total arsenic and inorganic arsenic in fish}

Arsenic exists in a variety of oxidation states and in both inorganic and organic forms. Marine foods have relatively 
high arsenic concentrations, due primarily to complex organic forms of arsenic such as arsenobetaine and arsenocholine. Most cases of arsenic-induced toxicity in humans are associated with inorganic arsenic exposure which has been classified as known human carcinogen. ${ }^{23}$ Studies on arsenic accumulation in freshwater fish show greater variation in results, with some species containing arsenobetaine as the main organic form, while As (III) has been shown to be the main arsenic content in the hepatopancreas of freshwater crayfish. ${ }^{24}$ Intake of inorganic arsenic over a long period can lead to chronic arsenic poisoning. Effects, which can take years to develop depending on the level of exposure, include skin lesions, peripheral neuropathy, gastrointestinal symptoms, diabetes, renal system effects, cardiovascular disease and cancer. ${ }^{25}$

Arsenic speciation in fish samples published in the literature indicates wide range of variability. Studies conducted in Taiwan and Thailand showed that the proportion of inorganic arsenic in fish ranges from 21 to $44.1 \%$ of total arsenic content. ${ }^{26,27}$ In several studies percentage of inorganic arsenic were shown to range from 5 to $20 \%$ of total arsenic. ${ }^{28-31}$ However, some studies reported lower percentages of inorganic arsenic ranging from 0.5 to less than $10 \%$ of total arsenic values in fish. ${ }^{32-36}$ In this study, the computation of carcinogenic health risk was based on the assumption that inorganic arsenic proportion is approximately $10 \%$ of the total arsenic content in fish samples.

Estimate of carcinogenic health risk due to fish consumption (dry season)

Life time carcinogenic risks for arsenic exposure were computed for five fish species in all sampling stations for dry season conditions. The highest life time cancer risk for arsenic during dry season was computed for tilapia from sampling station $2 \mathrm{~B}$ with risk value of $8.51 \times 10^{-5}$. This is an estimate of lifetime probability of an individual developing cancer as a result of long term consumption of tilapia, indicating risk that would result to about 85 excess cancer cases per 1,000,000 populations.

The lowest life time cancer risk for arsenic was computed for dalag and kanduli from sampling station 3B with risk value of $2.92 \times 10^{-9}$, showing that consumption would result to about 3 excess cancer cases per 100,000,000 populations.

Average life time cancer risks associated with fish consumption during the dry season for each of the five species based on mean arsenic levels in all sampling stations are summarized below.

For Bangus, the average risk is $1.86 \times 10^{-5}$; the risk is about 19 excess cancer cases per 1,000,000 populations. For Bighead Carp, the average risk is $3.495 \times 10^{-5}$; the risk is about 35 excess cancer cases per 1,000,000 populations. For Dalag, the average risk is $1.4612 \times 10^{-5}$; the risk is about 15 excess cancer cases per 1,000,000 populations. For Kanduli, the average Risk is $2.114 \times 10^{-5}$; the risk is about 21 excess cancer cases per 1,000,000 populations. For Tilapia, average risk is $3.772 \times 10^{-5}$; the risk is about 38 excess cancer cases per $1,000,000$ populations. Average life time cancer risks associated with fish consumption during dry season showed the following order of magnitude:

$$
\text { Tilapia }>\text { Bighead carp }>\text { Kanduli }>\text { Bangus }>\text { Dalag. }
$$

Estimate of carcinogenic health risk due to fish consumption (wet season)

Climate in the study site is characterized by relatively high temperature, humidity and rainfall. There are only two seasons, wet and dry season. Annual average rainfall ranges from as much as 5,000 millimeters near eastern coast section, to less than 1,000 millimeters in some of the sheltered valleys. Estimate of carcinogenic risks for both seasons were calculated to assess the possibility of seasonal variations in health risks.

The life time cancer risks for arsenic exposure were computed for five fish species in all sampling stations for wet season. Highest life time cancer risk for arsenic was computed for bighead carp from sampling station 4 with risk value of $1.87 \times 10^{-5}$, or about 19 excess cancer cases per $1,000,000$ populations. This is an estimate of lifetime probability of an individual developing cancer as a result of long term consumption of bighead carp.

Lowest life time cancer risk for arsenic was computed for dalag (sampling stations $2 A, 3 A$ and $3 B$ ), tilapia (sampling stations $1 A, 2 A$, and 5 ), and kanduli (sampling stations $2 A, 2 B$, $3 A, 3 B$ and 5 ) with risk value of $9.744 \times 10^{-8}$ or about 1 excess cancer case per 10,000,000 populations.

Average life time cancer risks associated with fish consumption (wet season) for each of the five fish species considering mean arsenic levels in all sampling stations are shown below.

For Bangus, the average risk is $8.5 \times 10^{-6}$; the risk is about 9 excess cancer cases per 1,000,000 populations. For Bighead Carp, the average Risk is $1.04 \times 10^{-5}$; the risk is about 11 excess cancer cases per 1,000,000 populations. For Dalag, the average risk is $1.81 \times 10^{-6}$; the risk is about 2 excess cancer cases per 1,000,000 populations. For Kanduli, the average risk is $3.3 \times 10^{-6}$; the risk is about 4 excess cancer cases per $1,000,000$ populations. For Tilapia, average risk is $2.76 \times 10^{-6}$; the risk is about 3 excess cancer cases per 1,000,000 populations. Average life time cancer risks associated with fish consumption during wet season showed the following order of magnitude:

$$
\text { Bighead carp }>\text { Bangus }>\text { Kanduli }>\text { Tilapia }>\text { Dalag. }
$$

Summary of computed lifetime cancer risks for individual fish species in all sampling sites during the dry and wet seasons is shown in Table 3 . 
Table 3. Summary of computed lifetime cancer risks from arsenic (dry and wet seasons).

\begin{tabular}{|c|c|c|c|c|c|c|c|c|c|}
\hline \multirow{2}{*}{$\begin{array}{c}\text { Fish samples } \\
\text { (DS) }\end{array}$} & \multicolumn{9}{|c|}{ Computed risk per sampling site (dry Season) } \\
\hline & $1 \mathrm{~A}$ & 1B & $2 \mathrm{~A}$ & 2B & $3 \mathbf{A}$ & 3B & 4 & 5 & Ave. Risk \\
\hline Bangus & $6.4 \mathrm{E}-05$ & 8.3E-06 & $1.8 \mathrm{E}-05$ & $8.6 \mathrm{E}-06$ & $1.2 \mathrm{E}-05$ & $5.6 \mathrm{E}-06$ & $1.4 \mathrm{E}-05$ & No data & 1.9E-05 \\
\hline Bighead Carp & 3.6E-05 & 6.9E-05 & $1.5 \mathrm{E}-05$ & 9.7E-05 & 9.3E-06 & $2.5 \mathrm{E}-05$ & $1.2 \mathrm{E}-05$ & 1.6E-05 & $3.5 \mathrm{E}-05$ \\
\hline Dalag & 3.6E-05 & 3.1E-06 & $1.5 \mathrm{E}-05$ & 2.2E-05 & $8.2 \mathrm{E}-06$ & 2.9E-09 & $1.1 \mathrm{E}-05$ & 2.1E-05 & $1.5 \mathrm{E}-05$ \\
\hline Kanduli & 3.6E-05 & $1.6 \mathrm{E}-06$ & $1.4 \mathrm{E}-05$ & $2.0 \mathrm{E}-05$ & 7.2E-05 & 2.9E-09 & $6.0 \mathrm{E}-06$ & $2.0 \mathrm{E}-05$ & 2.1E-05 \\
\hline Tilapia & 3.4E-05 & 5.4E-05 & 9.7E-06 & 8.5E-05 & 7.5E-05 & $1.4 \mathrm{E}-05$ & 2.9E-06 & 2.7E-05 & $3.8 \mathrm{E}-05$ \\
\hline \multirow{2}{*}{ (WS) } & \multicolumn{9}{|c|}{ Computed risk per sampling site (wet season) } \\
\hline & 1A & 1B & $2 \mathrm{~A}$ & 2B & $3 \mathbf{A}$ & 3B & 4 & 5 & Ave. Risk \\
\hline Bangus & $1.1 \mathrm{E}-05$ & 3.7E-06 & $5.1 \mathrm{E}-06$ & $1.1 \mathrm{E}-05$ & 8.7E-06 & $3.4 \mathrm{E}-06$ & $1.6 \mathrm{E}-05$ & No data & $8.4 \mathrm{E}-06$ \\
\hline Bighead Carp & 1.7E-05 & 2.8E-06 & $1.0 \mathrm{E}-05$ & 4.1E-06 & 1.7E-05 & 5.1E-06 & $1.9 \mathrm{E}-05$ & 8.2E-06 & $1.0 \mathrm{E}-05$ \\
\hline Dalag & 3.7E-06 & 4.6E-06 & 9.7E-08 & $7.0 \mathrm{E}-07$ & 9.7E-08 & 9.7E-08 & $2.5 \mathrm{E}-06$ & 2.7E-06 & $1.8 \mathrm{E}-06$ \\
\hline Kanduli & 7.8E-06 & 8.8E-06 & 9.7E-08 & 9.7E-08 & 9.7E-08 & 9.7E-08 & $9.3 \mathrm{E}-06$ & 9.7E-08 & 3.3E-06 \\
\hline Tilapia & 9.7E-08 & $1.6 \mathrm{E}-05$ & 9.7E-08 & 1.7E-07 & 4.1E-07 & 2.9E-07 & 5.3E-06 & 9.7E-08 & $2.8 \mathrm{E}-06$ \\
\hline
\end{tabular}

\section{Correlation analyses of fish mean standard size and arsenic concentration}

Previous studies have shown strong relationship between fish size and accumulation of heavy metals. This is often attributed to changes in metabolic activity as fish ages, where it is assumed that large fish are undergoing reduction in their metabolic activity. Changes in metabolic rate are thought to influence uptake of trace metals, creating strong relationship between body size and tissue concentrations of trace metals. ${ }^{37}$ Several studies have described both positive and negative relationships of fish size and heavy metals concentration. Natures of correlation were mostly dependent on the kind of heavy metals analyzed and species of fish. ${ }^{38-43}$ In a study of the relationship between heavy metal levels and fish size, the results of linear regression analysis showed negative relationship between the two variables investigated. ${ }^{44}$ However, a parallel study by Indrajith et al. showed that the levels of heavy metals in the fish muscle tissue were positively correlated with the length of fish. ${ }^{45}$
In this study, linear correlation analysis of fish standard size vis a vis arsenic concentration in the fish samples was done to determine whether the size of fish was correlated with levels of arsenic concentration.

Linear correlation coefficient of mean standard lengths of fish samples and corresponding concentrations of arsenic $(\mathrm{mg} / \mathrm{kg})$ for dry and wet seasons are shown in Table 4. Pearson product moment correlation coefficients ( $\mathrm{r}$ ) for each fish species were computed to determine linear relationship between the size of fish samples and heavy metal concentration. Computed (r) values ranged from -0.42 to 0.27 indicating that correlation between the two variables tested is either negative or weak positive relationship. This demonstrates that size of fish samples during dry season do not have considerable effect on concentration of arsenic. Comparable with the dry season results, the wet season values of $(\mathrm{r})$ ranged from -0.27 to 0.29 indicating weak correlation. This shows that fish sizes during wet season do not have significant effect on the levels of arsenic.

Table 4. Correlation coefficient of mean standard length of fish and Arsenic (As) concentration (dry and wet seasons).

\begin{tabular}{|c|c|c|c|c|c|c|c|c|c|c|}
\hline $\begin{array}{l}\text { Sampling Site } \\
\text { (Dry season) }\end{array}$ & $\begin{array}{c}\text { Bangus } \\
(\mathrm{cm})\end{array}$ & As ppm & $\begin{array}{c}\text { Bighead } \\
\text { Carp }(\mathrm{cm})\end{array}$ & As ppm & $\begin{array}{c}\text { Dalag } \\
(\mathrm{cm})\end{array}$ & As ppm & $\begin{array}{c}\text { Kanduli } \\
(\mathrm{cm})\end{array}$ & As ppm & $\begin{array}{c}\text { Tilapia } \\
\text { (cm) }\end{array}$ & As ppm \\
\hline $1 \mathrm{~A}$ & 34.3 & 0.66 & 59 & 0.37 & 26.0 & 0.37 & 23.2 & 0.37 & 31.7 & 0.35 \\
\hline 1B & 31.3 & 0.09 & 65 & 0.71 & 35.0 & 0.03 & 22.8 & 0.02 & 26.3 & 0.55 \\
\hline $2 \mathrm{~A}$ & 31.0 & 0.19 & 55 & 0.15 & 38.5 & 0.16 & 23.5 & 0.14 & 25.0 & 0.10 \\
\hline $2 B$ & 34.0 & 0.09 & 53 & 1.00 & 38.0 & 0.23 & 21.5 & 0.20 & 27.7 & 0.87 \\
\hline $3 \mathrm{~A}$ & 37.0 & 0.12 & 61 & 0.10 & 31.0 & 0.08 & 19.0 & 0.74 & 21.0 & 0.77 \\
\hline $3 B$ & 36.7 & 0.06 & 50 & 0.26 & 38.0 & 0.00 & 20.5 & 0.00 & 19.8 & 0.15 \\
\hline 4 & 29.7 & 0.14 & 56 & 0.12 & 25.7 & 0.11 & 31.7 & 0.06 & 22.3 & 0.03 \\
\hline 5 & No data & & 61 & 0.16 & 30.7 & 0.22 & 24.0 & 0.21 & 22.0 & 0.28 \\
\hline $\begin{array}{l}\text { Correlation (r) } \\
\text { (Wet season) }\end{array}$ & & 0.02 & & -0.02 & & -0.42 & & -0.44 & & 0.27 \\
\hline $1 \mathrm{~A}$ & 29.0 & 0.109 & 43.0 & 0.172 & 28.5 & 0.038 & 20.0 & 0.080 & 28.0 & 0.001 \\
\hline $1 B$ & 20.0 & 0.038 & 50.0 & 0.029 & 46.0 & 0.047 & 19.0 & 0.090 & 18.7 & 0.161 \\
\hline $2 \mathrm{~A}$ & 23.0 & 0.053 & 49.0 & 0.105 & 39.0 & 0.001 & 18.4 & 0.001 & 18.8 & 0.001 \\
\hline $2 B$ & 19.2 & 0.118 & 56.0 & 0.042 & 35.0 & 0.007 & 19.2 & 0.001 & 30.5 & 0.002 \\
\hline $3 \mathrm{~A}$ & 42.0 & 0.089 & 48.0 & 0.178 & 39.5 & 0.001 & 19.8 & 0.001 & 20.3 & 0.004 \\
\hline $3 B$ & 37.5 & 0.035 & 33.5 & 0.052 & 37.0 & 0.001 & 23.3 & 0.001 & 15.8 & 0.003 \\
\hline 4 & 35.5 & 0.168 & 63.0 & 0.192 & 30.0 & 0.026 & 24.5 & 0.095 & 22.7 & 0.054 \\
\hline 5 & No data & & 42.0 & 0.084 & 44.0 & 0.028 & 28.0 & 0.001 & 22.0 & 0.001 \\
\hline Correlation (r) & & 0.17 & & 0.29 & & 0.06 & & -0.06 & & -0.27 \\
\hline
\end{tabular}




\section{Conclusion}

This study spatially analyzed the potential carcinogenic risk associated with consumption of commercially significant edible fish from Laguna de Bay considering the effects of seasonal variation in potential health risks. In general, estimates of carcinogenic risk to fish consumers were higher during the dry season than wet season. In terms of spatial distribution of health risk, calculated values showed that it was fairly distributed in most of the fishing areas around the lake except for south bay and central west bay. The probable risks in these areas were relatively lower than other fishing grounds in the lake during dry season. Health risk also differs according to fish species and season, during dry season it showed the following order of magnitude, Tilapia $>$ Bighead Carp $>$ Kanduli $>$ Bangus $>$ Dalag and for wet season, Bighead Carp $>$ Bangus $>$ Kanduli $>$ Tilapia > Dalag. Tilapia and bighead carp have the highest carcinogenic risks for dry and wet seasons, respectively. On the other hand, dalag exhibited the lowest risk among fish species for both seasons. Correlation analyses showed that fish mean standard sizes do not have significant effect on levels of arsenic in fish samples for both seasons.

Results of this study represent single pollutant and species-specific fish consumption exposure via ingestion. Although calculation of carcinogenic health risks for multiple route and exposure pathways is theoretically possible, it would require tremendous effort beyond the scope of this study. Nevertheless, this study showed that through fish ingestion alone the average carcinogenic risk due to arsenic levels exceeded typical acceptable risk $\left(1 \times 10^{-6}\right)$. This study concludes from the point of view of disease prevention that long-term consumption of five commercially important fish species from Laguna de Bay may cause significant carcinogenic health risk.

\section{Acknowledgments}

This research was primarily supported by the Research Institute for Humanity and Nature, Kyoto, Japan and the Philippine government through the LakeHEAD project on Managing Environmental Risks to Food and Health Security in Southeast Asian Watersheds. Sincere appreciation to the following scientists for their insights and guidance: Dr. Maria Victoria O. Espaldon, Dr. Enrique P. Pacardo, Dr. Maxima E. Flavier, Dr. Carmelita M. Rebancos, Dr. Lynn Crisanta Panganiban and Ms. Adelina Santos-Borja. The authors would like to thank Laguna Lake Development Authority, the fishermen in lakeshore communities, and the entire LakeHEAD team for their support. Special thanks are extended to the Industrial Technology Development Institute, Department of Science and Technology Laboratory for the analyses of fish samples and to the Department of Environmental and Occupational Health, College of Public Health University of the Philippines Manila, the Department of Science and Technology, and the Research Institute for Humanity and Nature for the financial assistance to this research work. Above all, highest honor and gratitude is given to our Heavenly Father, our God Almighty who provides everything we need, to GOD be the glory!

\section{References}

1. Yousafzai AM, Chivers D, Khan AR, Ahmad I, Siraj M. Comparison of heavy metals burden in two freshwater fishes wallago attu and labeo dyocheilus with regard to their feeding habits in natural ecosystem. Pakistan J Zool. 2010; 42(5):537-44.

2. Abdel-Baki AS, Dkhil MA, Al-Quraishy S. Bioaccumulation of some heavy metals in tilapia fish relevant to their concentration in water and sediment of wadi hanifah, Saudi Arabia. Afr J Biotechnol. 2011; 10(13):2541-7.

3. Yi YJ, Zhang SH. The relationship between fish heavy metal concentrations and fish size in the upper and middle reach of Yangtze River. Procedia Environ Sci. 2012; 13:1699-1707.

4. Lakshmanan R, Kesavan K, Vijayanand P, Rajaram V, Rajagopal S. Heavy metals accumulation in five commercially important fishes of parangipettai, southeast coast of India. Advance Journal of Food Science and Technology. 2009; 1(1):63-5.

5. Vieira C, Morais S, Ramos S, Delerue-Matos C, Oliveira MB. Mercury, cadmium, lead and arsenic levels in three pelagic fish species from the Atlantic Ocean: intra- and inter-specific variability and human health risks for consumption. Food Chem Toxicol. 2011; 49(4):923-32.

6. Obinaju BE. Mechanisms of arsenic toxicity and carcinogenesis. Afr J Biochem Res. 2009; 3(5):232-7.

7. Sangeeta D, Balagopalan U, Minakshi B, Sawlang BW, Paruchuri GR. Toxicological effects of arsenic exposure in freshwater teleost fish, channa punctatus. Afr J Biotechnol. 2012; 11(19):4447-54.

8. Azizur Rahman M, Hasegawa H. Arsenic in freshwater systems: influence of eutrophication on occurrence, distribution, speciation and bioaccumulation. Appl Geochem. 2012; 27(1):304-14.

9. Liao CM, Shen $\mathrm{HH}$, Lin TL, et al. Arsenic cancer risks posed to human health from tilapia consumption in Taiwan. Ecotoxicol Environ Saf. 2008; 70(1):27-37.

10. Toxicity Profile for Arsenic [Online]. [cited 2012 Nov]. Available from http://rais.ornl.gov/tox/profiles/arseni_c.html.

11. Sirot V, Guerin T, Volatier JL, Leblanc JC. Dietary exposure and biomarkers of arsenic in consumers of fish and shellfish from France. Sci Total Environ. 2009; 407(6):1875-85.

12. Agency for Toxic Substances and Disease Registry (ATSDR). Toxicological profile for Arsenic [Online]. [cited 2012 Nov]. Available from www.atsdr.cdc.gov/toxprofiles/tp2-c6.pdf.

13. Liu CW, Liang CP, Huang FM, Hsueh YM. Assessing the human health risks from exposure of inorganic arsenic through oyster (crassostrea gigas) consumption in Taiwan. Sci Total Environ. 2006; 361(1-3):57-66.

14. Nor Hasyimah AK, James Noik V, Teh YY, Lee CY, Pearline Ng HC. Assessment of cadmium (Cd) and lead $(\mathrm{Pb})$ levels in commercial marine fish organs between wet markets and supermarkets in Klang Valley, Malaysia. International Food Research Journal. 2011; 18:795-802.

15. Domingo JL, Bocio A, Falco G, Llobet JM. Benefits and risks of fish consumption Part 1.A quantitative analysis of the intake of omega-3 fatty acids and chemical contaminants. Toxicology. 2007; 230(2-3):219-26.

16. Mozaffarian D, Rimm EB. Fish intake, contaminants, and human health: evaluating the risks and the benefits. JAMA. 2006; 296(15):1885-99.

17. Hoekstra J, Hart A, Owen H, et al. Fish, contaminants and human health: quantifying and weighing benefits and risks. In Press, Food Chem Toxicol. 2013; 54:18-29.

18. Lee JJ, Jang CS, Liang CP, Liu CW. Assessing carcinogenic risks associated with ingesting arsenic in farmed smeltfish (ayu, plecoglossus altirelis) in aseniasis-endemic area of Taiwan. Sci Total Environ. 2008; 403(1-3):68-79.

19. USEPA (US Environmental Protection Agency), Human Health Risk Assessment [Online]. [cited 2012 Nov]. Available from http://www.epa.gov/risk_assessment/health-risk.htm.

20. World Health Organization (WHO), Human Health Risk Assessment Toolkit: Chemical Hazards. International Program for Chemical Safety [Online]. 2010 [cited 2012 Nov]. Available from http://www.who.int/ipcs/publications/methods/harmonization/toolkit.p df. 
21. A Guide to Health Risk Assessment. California Environmental Protection Agency, Office of Environmental Health Hazards Assessment [Online]. [cited 2012 Nov] Available from http://oehha.ca.gov/pdf/HRSguide2001.pdf.

22. Lasco RD, Espaldon MVO, Tapia MA. Ecosystems and people: the Philippine millennium ecosystem assessment sub-global assessment, Laguna de Bay, Philippines. 2005.

23. Meacher DM, Menzel DB, Dillencourt MD, Bic LF, Schoof RA, Yost LJ, Eickhoff JC, Farr CH. Estimation of multimedia inorganic arsenic intake in the U.S. Population. Hum Ecol Risk Assess. 2002; 8(7):1697-1721.

24. Williams G, West JM, Koch I, Reimer KJ, Snow,ET. Arsenic speciation in the freshwater crayfish, Cherax destructor Clark. Sci Total Environ. 2009; 407(8):2650-8

25. World Health Organization (WHO), Exposure to Arsenic: A Major Public Health Concern [Online]. [cited 2012 Dec]. Available from http://www.who.int/ipcs/features/arsenic.pdf.

26. Lin HT, Chen SW, Shen CJ, Chu C. Arsenic speciation in fish on the market. J Food Drug Anal. 2008; 16(4):70-5.

27. Ruangwises N, Saipan $P$, Ruangwises $S$. Total and inorganic arsenic in natural and aquacultural freshwater fish in Thailand: a comparative study. B Environ Contam Tox. 2012; 89: 1196-200.

28. Norin H, Vahter M, Christakopoulos A, Sandstrom M. Concentration of inorganic and total arsenic in fish from industrially polluted water. Chemosphere. 1985; 14(3-4):325-34.

29. Kar S, Maity JP, Jean JS, et al. Health risks for human intake of aquacultural fish: Arsenic bioaccumulation and contamination. J. Environ Sci Health A Tox Hazard Subst Environ Eng. 2011; 46(11):126673.

30. Lorenzana RM, Yeow AY, Colman JT, Chappell LL, Choudhury H. Arsenic in seafood: speciation issues for human health risk assessment. Human and Ecological Risk Assessment: An International Journal. 2009; 15(1):185-200.

31. Schoof RA, Yager JW. Variation of total and speciated arsenic in commonly consumed fish and seafood. Human and Ecological Risk Assessment: An International Journal. 2007; 13(5):946-65.

32. Greene R, Crecelius E. Total and inorganic arsenic in mid-atlantic marine fish and shellfish and implications for fish advisories. Integr Environ Assess Manag. 2006; 2(4):344-54.

33. de Rosemond S, Xie Q, Liber K. Arsenic concentration and speciation in five freshwater fish species from Back Bay near Yellowknife, NT, Canada. Environ Monit Assess. 2008; 147(1-3):199-210.

34. Huang $\mathrm{YK}$, Lin $\mathrm{KH}, \mathrm{Chen} \mathrm{HW}$, et al. Arsenic species contents at aquaculture farm and in farmed mouthbredder (Oreochromis mossambicus) in blackfoot disease hyperendemic areas. Food Chem Toxicol. 2003; 41(11):1491-500.

35. Peshut PJ, Morrison RJ, Brooks BA. Arsenic speciation in marine fish and shellfish from American Samoa. Chemosphere. 2008; 71(3):484-92.

36. De Gieter M, Leermakers M, Van Ryssen R, Noyen J, Goeyens L, Baeyens W. Total and toxic arsenic levels in north sea fish. Arch Environ Contam Toxicol. 2002; 43:406-17.

37. McKinley AC, Taylor MD, Johnston EL. Relationship between body burdens of trace metals ( $\mathrm{As}, \mathrm{Cu}, \mathrm{Fe}, \mathrm{Hg}, \mathrm{Mn}, \mathrm{Se}$, and $\mathrm{Zn}$ ) and the relative body size of small tooth flounder (Pseudorhombus jenynsii). Sci Total Environ. 2012; 423:84-94.

38. Yi YJ, Zhang SH. Heavy metal (Cd, Cr, Cu, Hg, Pb, Zn) concentrations in seven fish species in relation to fish size and location along the Yangtze River. Environ Sci Pollut Res Int. 2012; 19(9):3989-96.

39. Garcia-Montelongo F, Diaz C, Galindo L, Larrechi MS, Rius X. Heavy metals in three fish species from the coastal waters of Santa Cruz de Tenerife (Canary Islands). Sci Mar. 1994; 58(3):179-83.

40. Al-Yousuf MH, El-Shahawi, Al-Ghais SM. Trace metals in liver, skin and muscle of Lethrinus lentjan fish species in relation to body length and sex. Sci Total Environ. 2000; 256(2-3):87-94.

41. Imanpour Namin J, Mohammadi M, Heydari S, Monsef Rad F. Heavy metals $\mathrm{Cu}, \mathrm{Zn}, \mathrm{Cd}$, and $\mathrm{Pb}$ in tissue, liver of esox lucius and sediment from the Anzali international lagoon - Iran. Caspian Journal of Environmental Sciences. 2011; 9(1):1-8.

42. Authman MMN. Oreochromis niloticus as a biomonitor of heavy metal pollution with emphasis on potential risk and relation to some biological aspects. Global Veterinaria. 2008; 2(3):104-9.
43. Farkas A, Salanki J, Specziar A. Age- and size-specific patterns of heavy metals in the organs of freshwater fish Abramis brama L. populating a low-contaminated site. Water Res. 2003; 37(5):959-64.

44. Canli M, Atli G. The relationship between heavy metal $(\mathrm{Cd}, \mathrm{Cr}, \mathrm{Cu}, \mathrm{Fe}$, $\mathrm{Pb}, \mathrm{Zn}$ ) levels and the size of six Mediterranean fish species. Environ Pollut. 2003; 121(1):129-36.

45. Indrajith HAP, Pathiratne KAS, Pathiratne A. Heavy metal levels in two food fish species from Negombo estuary, Sri Lanka: relationship with the body size. Sri Lanka J Aquat Sci. 2008; 13:63-81. 